\title{
SUPPORTING THE WATER RESERVOIR RESTORATION PROCESSES BY USING SELECTED TYPE OF BIOLOGICAL BEDS
}

\author{
Agata Mazur ${ }^{1 凶}$, Krzysztof Chmielowski $^{2}$ \\ ${ }^{1}$ Department of Geoformation Photogrammetry and Remote Sensing of Environment, Faculty of Mining Surveying and Environ- \\ mental Engineering, AGH University of Science and Technology, al. Mickiewicza 30, 30-059 Kraków \\ 2 Department of Sanitary Engineering and Water Management, Faculty of Environmental Engineering and Land Surveying, \\ University of Agriculture in Krakow, al. Mickiewicza 21, 31-120 Kraków
}

\begin{abstract}
Aim of the study

The work aims to assess the possibility of the application of selected types of biological beds to support the revitalization processes of strongly degraded water reservoirs.

Material and methods

The authors reviewed the literature on biological methods used in the treatment processes of various types of wastewater. Certain types of beds have been selected that show tolerance to temperature changes and significant changes in organic pollutant loads. The self-purification potential of water and the role of natural methods in the revitalization of water reservoirs were characterized. The characteristics of biological methods based on MBBR moving and fixed beds are presented.
\end{abstract}

\section{Results and conclusion}

The possibility of application of selected types of MBBR moving and fixed beds in supporting the treatment of highly contaminated surface waters were assessed. Biotechnological methods based on liquid and solid biopreparations normally used in water revitalization were discussed. It has been shown that when biotechnological methods are not able to operate efficiently, it is very beneficial to start additional biological processes to improve the efficiency of the revitalization process.

Keywords: biological beds, biomass carriers, MBBR, nonwoven filters, mineral filters, water pollution, water treatment

\section{INTRODUCTION}

The nature of pollution of water reservoirs strictly determines the choice of specific methods of their revitalization (Chin, 2012; Cooke et al., 2016). The deterioration of water quality varies depending on the type of mixture of water pollutants and its load.. These pollutants cause several adverse environmental effects as a result of many processes that take place in the changed aquatic environment. The toxic effects are leading to the extinction of key species and the decline in biodiversity in aquatic ecosystems (Dumont et al., 2012; Butt et al., Cooke et al., 2016). The processes of biodegradation by different types of pollutants (i.e. detergents, easily-soluble organics, etc.) introduce into the water significant loads of nutrients responsible for the increase in water trophy (Khan \& Mohammad, 2014; Mazurkiewicz et al., 2020). The effects of eu-

凶e-mail:agata.nowak1992@gmail.com 
trophication in strongly eutrophic and hypertrophic reservoirs include intense algae blooms, a decrease in the light permeability of water, oxygen depletion, reduction of water transparency, etc. (Livingston, 2000; de Jonge et al., 2002; Zaldívar et al., 2008). Due to secondary intoxication and hypoxic conditions fish are dying and the sensitive aquatic species are being extinct. The development of cyanobacteria may additionally cause an increase in the concentration of cyanobacterial metabolites (strong poisons for human health and aquatic organisms development) (Falconer, 1996; Stewart et al., 2008). Strongly eutrophic and hypertrophic reservoirs are mainly located in agricultural and industrial areas, where wastewater rich in nutrients and loads of easily-soluble organics are discharged into the water (Álvarez et al., 2017; Huang et al., 2017). In industrial areas with the extraction of minerals and the processing of petroleum substances, one can find heavily degraded reservoirs (ponds, lakes, rivers) with waters polluted with high loads of petroleum derivatives (high concentrations of the phenol index, cresols, PAHs, PCBs, dioxins, polychlorinated biphenyls, pesticide derivatives and other types of aromatic and aliphatic hydrocarbons substances). Such polluted waters are characterized by very poor biodiversity, only very tolerant species can survive here (McGuire et al., 2018; Wang et al., 2018; Ontiveros-Cuadras et al., 2018). High water pollution is accompanied by intensive accumulation of bottom sediments (soft organic fractions), the transformations of which in anaerobic conditions cause harm to the aquatic environment and produce odors in the vicinity of the degraded reservoir (Das, 2005; Qiu, 2010). In heavily degraded reservoirs, the development of pathogenic microorganisms (mainly anaerobes or facultative anaerobes) is observed, which are an additional problem for the weakened water ecosystem (Han and Park, 1999; Gough \& Stahl, 2011). Such changed tanks are not able to carry out the self-purification process, due to significant loads with mixtures of pollutants and the domination of pathogenic microorganisms (Mazur and Sitarek, 2020). To revitalize these reservoirs, several engineering works are needed depending on the nature of the changes and operating costs that these might require. The dynamic development of environmental biotechnology provides many methods that can be used to effectively counteract degradation and quickly eliminate specific types of pollution. The certified biopreparations in a solid and liquid form available on the market contain allochthonous forms of microorganisms capable of efficient removal of many forms of organic and inorganic contamination (Mazur, 2020). Some industrial solutions in wastewater treatment can also be adapted to a certain extent in order to support biological methods of the revitalization of heavily changed water reservoirs. (Sitarek et al., 2017).

Biological beds currently play a key role in wastewater treatment and industrial pollution processes (Juang et al., 2008; Nakamura and Mueller, 2008; Ateia et al., 2015; Ateia et al., 2016; Mazur, 2019A; Mazur, 2019b; Mazur 2020, Nowak et al., 2018; Nowak et al., 2019). The scientific literature contains numerous publications on pollution treatment technologies based on various types of biological beds (Andreottola et al., 2000; Ødegaard et al., 2004; Leiknesand and Ødegaard, 2007; McQuarrie and Boltz, 2011; Cao et al., 2012). The dynamic development of environmental engineering provides us with a significant number of various natural and artificial materials that can be successfully used as biomass carriers (Moga et al., 2000; Wilderer et al., 2000; Andersson et al., 2008; Walters et al., 2009; Lu et al., 2018; Zainab et al., 2020).

The main purpose of the article was to review scientific and industry information on the possibility of using artificial methods of biological treatment of polluted surface waters.

\section{METHODS AND MATERIALS}

The authors made a broad and thorough review of current knowledge based on the scientific literature along with the most recent articles in Web of science, Scopus and other resources, and scientific books.

Based on the literature data, the authors described and assessed the best solutions in the field of environmental biotechnology that can be used in the revitalization of water reservoirs. The scientific rationale and proposed solutions for systems based on selected types of biological deposits have been presented, highlighting those with the highest potential for providing solutions supporting the process of purification polluted waters in freshwater reservoirs. The authors assessed the usefulness of selected biological methods 
Mazur, A., Chmielowski, K. (2020). Supporting the water reservoir restoration processes by using selected type of biological beds. Acta Sci. Pol., Formatio Circumiectus, 19 (3), 83-98. DOI: http://dx.doi.org/10.15576/ASP.FC/2020.19.3.83

in terms of highly degraded reservoirs with significant loads of mixtures of pollutants. Oligo and mesotrophic reservoirs have not been assessed, as they can be successfully revitalized through self-purification processes or by creating natural or artificial wetland zones (ecotones) that have a high purification potential for many groups of pollutants (Wang et al., 2010, Ham et al., 2010).

\section{The characteristics of microbiota in AS and biofilm}

The biological bed category includes structures such as activated sludge (AS) flocs and biofilm growing on a specific type of fixed or mobile carriers (Badejo et al., 2017; Wang et al., 2020). The main element of the bed is the consortia of microorganisms that form artificial ecosystems and food webs which feed on organic pollutants (for organic carbon or energy) (Zhang et al., 2017; Qin et al., 2018). The activated sludge structures are based on the formation of irregular flocculent structures (in the process of natural flocculation). The main medium on which the entire micro-community develops is the extracellular secretions matrix (ECS) of Zooglea sp. (Shao et al., 2009). The active surface of such structures in the wastewater volume is significant and depending on the contact time of pollutants with the activated sludge, the process of biodegradation of pollutants is more or less effective. A biofilm is also a form of biologically active surface in which the microbiota are embedded in the form of a biological membrane on mineral or artificial carriers (Andreadakis, 1993). In this case, also the cell secretions of various strains of bacteria from the Zoogloeaceae family form the contact surface of these micro-biocoenoses with wastewater or pollutants of surface waters (Nagaoka et al., 1996; Vanrolleghem, 2002, Tzeng et al., 2003). The third form of "biological bed" are consortia of bacteria and free-living microorganisms that effectively exploit the food base, conducting the processes of biodegradation of organic compounds in polluted waters $(\mathrm{Qu}$ and Fan, 2010). Free-living bacteria are a natural component of aquatic ecosystems and play a key role in the circulation of matter as microorganisms that conduct the processes of mineralization of organic compounds (Fuhrman, 1992). The last type of biological bed are microorganisms of the rhizosphere of aquatic macrophytes, which form one of the most effective natural biofilters (Kuiper et al., 2004). Bacteria of the rhizosphere live in symbiosis with plants and carry out intensive biodegradation processes of dead organic matter in bottom sediments (Joner and Leyval, 2003). In the course of evolution, most macrophytes have developed efficient systems that transport atmospheric gases to the root systems. The anoxic conditions of the bottom zone do not pose a problem for the development of the rhizosphere. Oxygen conditions prevail

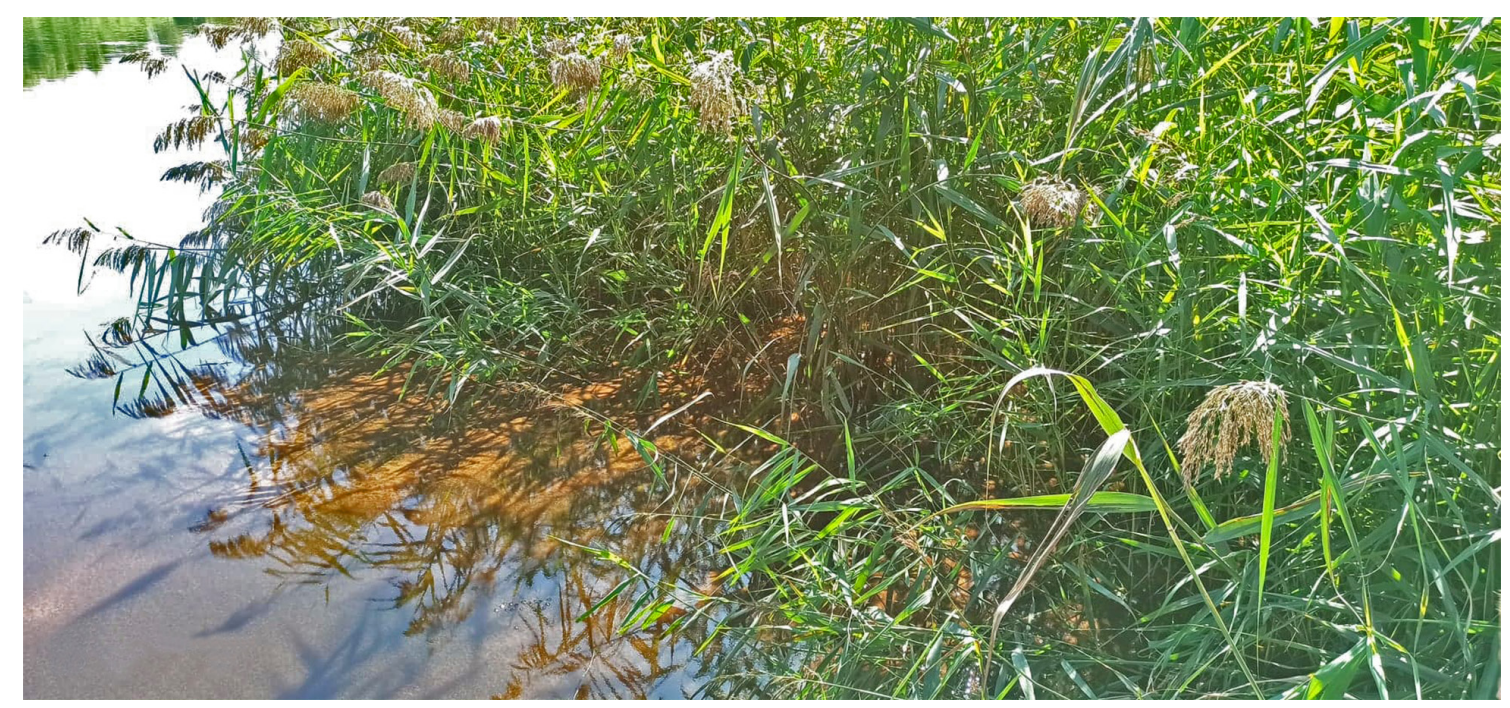

Fig. 1. Natural wetlands with the Phragmites australis monoculture in the conditions of an extremely polluted reservoir (photo by A. Mazur) 
within $0.3 \mathrm{~mm}$ of the root covering tissue (Sorrell and Dromgoole, 1987). Natural marshes dominated by the species Phragmites australis and other macrophytes form a very effective system for the purification of all kinds of organic pollutants (Zedler, 2000). In environmental engineering, wetlands treatment systems have been used as reservoirs in small and large wastewater treatment plants for many decades (Cooper, 1999; Brix et al., 2007). Both the rhizosphere bacteria of aquatic macrophytes and free-living microorganisms are responsible for the self-purification processes of surface waters (Ostroumov, 2017).

Both types of reservoirs contain indigenous species of aquatic microorganisms, which are an essential part of a self-controlling ecosystem.

\section{Pollution loads and purification processes}

The self-purification ability of surface waters is limited by environmental conditions, i.e. the number of natural swamps in the shoreline of the reservoir and the degree of coverage by submerged and floating macrophytes. Along with the influx of pollutants to the reservoir, we observe a gradual reduction in biodiversity in aquatic ecosystems (Maiti and Chowdhury, 2013). If the emission of pollutants is also continuous, then over a certain period, significant degradation of such a reservoir can occur and the maximum simplification of biodiversity (Johnston and Roberts, 2009). The processes of reproduction of renewable resources are inhibited and the number of tolerant species begins to increase (Johnston and Roberts, 2009). Also, even though some species are able to adapt to the new conditions of water quality, indigenous microorganisms are not able to purify it effectively (Hertkorn et al., 2002). Critical values of pollutant loads in the reservoir may cause irreversible changes in the aquatic environment and generate odor and aesthetic deterioration around the reservoir (Sutton et al., 2014).

In the case of significant degradation of the aquatic environment, measures should be taken to restore the appropriate water quality and regenerate the biodiversity of the reservoir (Effler, 1996). If only the nature of the pollutants allows the use of biological treatment methods, their selection should be a priority (Gołdyn et al., 2014; Cook et al., 2016). In the selection of biological (biotechnological) methods, technologies of microbiological biopreparations and supporting meth- ods such as ecotones and systems improving the oxygen conditions of the water are used. In the initial stage of the revitalization of significantly degraded reservoirs, it is advisable to use additional bed forms increasing the efficiency of the treatment process (Lariyah et al, 2016). The scientific literature shows a significant number of water bodies with an irreversible level of degradation, requiring the use of engineering technologies and artificial actions to eliminate various groups of pollutants (Ilnicki and Zeitz, 2002; Goel, 2006; Tripathi and Pandey, 2009; Wei et al., 2009; Palanques et al., 2014; Smil, 2015). In such cases, natural processes are incapable of activating the self-purification mechanisms in a polluted aquatic environment (Wei et al., 2009; Chen et al., 2012; Ostroumov, 2017).

\section{Types of biological beds and their applications}

Despite the four main forms of biological beds, many detailed types are distinguished depending on the technological applications and the types of processes in which they are used.

Fixed beds: constitute a significant group of biological membrane carriers for municipal and industrial wastewater treatment processes (Borghei et al., 2008). In wastewater treatment technologies, these beds play a key role in the selection and configuration of the treatment process in various flow, quasi-flow bioreactor systems (Lemmer et al., 1997).

Moving beds: one of the most dynamically developing treatment technologies in the last two decades. The working environment for this type of bed is the classic MBBR (moving bed biofilm reactor) reactors and their numerous modifications in hybrid systems (Ødegaard et al., 2004; Kujawiak et al., 2017; Kujawiak et al., 2018; Kujawiak et al., 2020). A significant number of this type of treatment plants based on MBBR technology has been built worldwide. Many SBR (sequencing batch reactor) reactors have been adapted to work in MBBR mode in hybrid mode (biomass carriers and activated sludge). Due to the high tolerance of MBBR bioreactors to changes in pollutant load and temperature of the treated medium, the scope of their application has been significantly extended (Andreottola et al., 2000). Many scientists and technologists conduct research on the development of biomass carriers and their selection for new processes and types of wastewater (Ateia et al., 2015; Ateia et al., 2016). 
Mazur, A., Chmielowski, K. (2020). Supporting the water reservoir restoration processes by using selected type of biological beds. Acta Sci. Pol., Formatio Circumiectus, 19 (3), 83-98. DOI: http://dx.doi.org/10.15576/ASP.FC/2020.19.3.83

\section{Biomass (biofilm) carriers}

\section{MBBR system}

Research and development works in the area of biomass carriers (biofilm) are of an interdisciplinary nature as they combine the mechanics of two-phase fluids, material science, and microbiology. A necessary condition for the use of fittings in MBBR biofilters is their density, which allows them to float freely in the water and at the same time to fall freely in a two-phase mixture (water-air). The hydrophobicity of the material used must not exceed a degree that prevents the biological membrane from freely covering the surface of the support (Sonwani et al., 2019). The specific surface area of the fittings should be as large as possible per $1 \mathrm{~m}^{3}$ of the beds used (Sonwani et al., 2019). The shape of the carriers must ensure a free circulation of the fittings in a bed, and at the same time, it cannot cause significant abrasion of the biofilm by collisions of the carriers (Kruszelnicka et al., 2018). The time of insertion of the biological membrane in a bed is variable and depends on the oxygen conditions, pollutant loads, and the possibility of additional inoculation of a bed with an appropriate microflora in the MBBR bioreactor (Morgan-Sagastume, 2018).

There are various types of fittings available on the market for MBBR systems, and their specific surface area per $1 \mathrm{~m}^{3}$ is very diverse. The most efficient and effective fittings are Mutag BioChip 30 ${ }^{\mathrm{TM}}$, which has an active surface of $5,000 \mathrm{~m}^{2} \cdot \mathrm{m}^{-3}$ (Fig. 2). Other biomass carriers used in industrial practice have an area at least 5 times smaller per $1 \mathrm{~m}^{3}$. The proper fouling of the surface of a shaped body by a biological membrane (biofilm) is assumed to be in the range of $0.3-0.5 \mathrm{~mm}$ (Rauch, 2014; Geiger and Rauch, 2017), for which it is possible to efficiently transport oxygen to the inside of the membrane.

\section{Other biomass carriers}

Many scientific publications have described the results of comparisons between different types of carriers and bioreactor environments in which they functioned as biological beds (Mamatarkova et al., 2002; Rauch, 2014; Al-Amshawee et al., 2020). The most important parameter characteristic for all types of biological beds is the active surface of the biofilm covering the beds. The flow of the medium must also be properly directed, and its speed should ensure the proper time of contact of pollutants with the biological bed.

The selection of biological beds depends on many parameters of the reservoir, i.e. the size of the reservoir, the concentration of contaminants (load sizes), the designed treatment system, and whether it is artificial or natural. Unfortunately, very often the costs of the treatment process, which are often significant per 1 ha (Martin, 2004; Le et al., 2010), play a key role.

Moving beds made of artificial materials such as PE, PP, PVC, ABS, etc. are mainly used in various

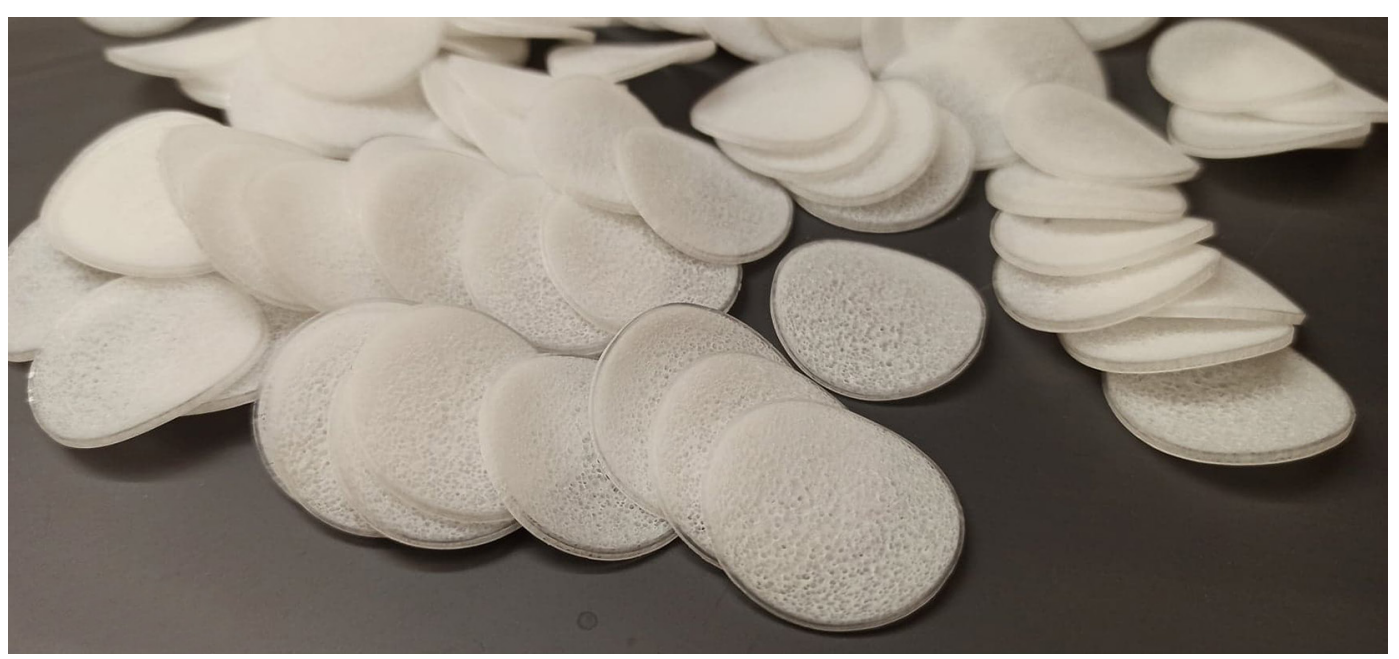

Fig. 2. Biofilm carriers include Mutag BioChip $30^{\mathrm{TM}}, 30 \mathrm{~mm}$ diameter each fitting, $1.1 \mathrm{~mm}$ thickness (photo by A. Mazur) 
types of sewage treatment plants, but also offer a possibility of their application to natural reservoirs requiring treatment (Andersson et al., 2008).

In the treatment of municipal and industrial wastewater in the world, Kaldnes fittings (see: Fig. 3 D) are the most widely used (Andreottola et al., 2000; Ødegaard et al., 2004). Bioball media beds (see: Fig. $3 \mathrm{H}$ ) or recycled Hel-x media (see: Fig. 3 A) are often used in the treatment of small reservoirs or on-site treatment plants. Also, the products of direct plastic grinding can act as biomass carriers (see: Fig. 3 F). In financial terms, fragments of cut conduit electric cables are an alternative (see: Fig. 3 B). Recycling beds are a cheap form of bed, unfortunately, their specific surfaces are not as significant as Kaldnes or Mutag BioChip (see: Fig. 3 C).

Common forms of beds in flow-through biofilters are expanded clay pellets (see: Fig. 3 E) and various types of ceramic fittings (see: Fig. $3 \mathrm{G}$ ) (Łopata et al., 2017). LECA has a significantly larger specific surface compared to ceramic carriers. Preliminary studies by Mazur indicate that microflora works significantly in the expanded clay in comparison to ceramic fittings and other types of biological beds.
Non-woven beds and sponges are still a popular form of filling in flow filters or as so-called backing biostructures in water bodies (see: Fig. 3 I, 4) (Mulligan et al., 2009).

This type of beds becomes clogged very quickly and the biomass that grows inside the pores inside the structures is subject to putrefactive processes. Fiber-filled biofilters require frequent cleaning, therefore their use in the treatment of water bodies is limited (mainly in small aquaculture reservoirs) (Zakaria et al., 2010).

One of the methods of lake and aquaculture reservoir treatment is a modified form of using EM preparations. The developed mudball bokashi contains effective consortia of microorganisms from the group of probiotics (see: Fig. 5). This method is becoming more and more popular all over the world, targeting contaminated shallow water bodies. According to the methodology developed by EM Probiotic technologists, about 1 mudball is used per $1 \mathrm{~m} 2$ of the reservoir at a depth of $1 \mathrm{~m}$ (bin Ahmad Nazria and binti Ghazali, 2017). Dissolving clay in water successively releases microorganisms that carry out bottom-up biodegradation processes. This method works especially well in small reservoirs

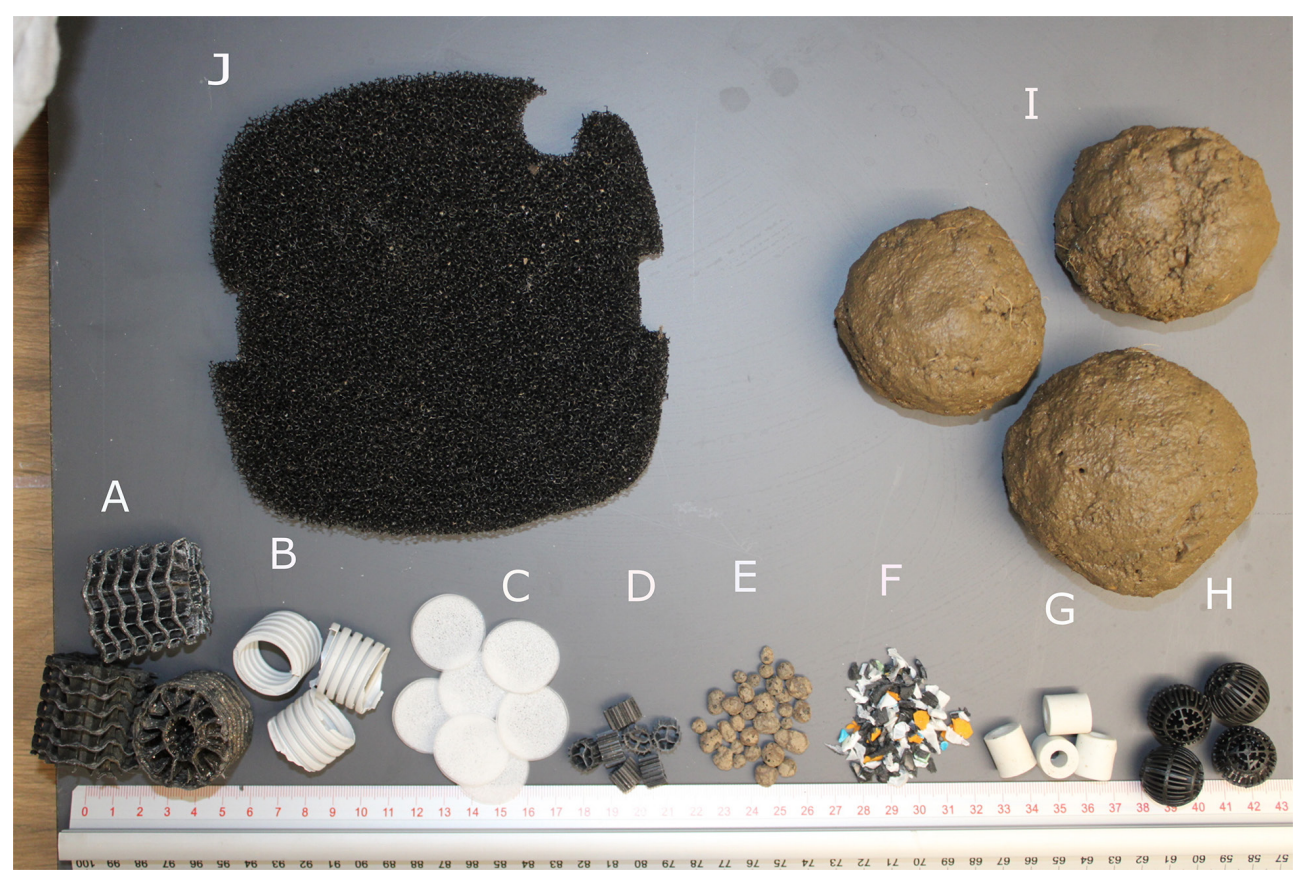

Fig. 3. Various biomass carriers used in the treatment of wastewater and water reservoirs (photo by A. Mazur) 
Mazur, A., Chmielowski, K. (2020). Supporting the water reservoir restoration processes by using selected type of biological beds. Acta Sci. Pol., Formatio Circumiectus, 19 (3), 83-98. DOI: http://dx.doi.org/10.15576/ASP.FC/2020.19.3.83

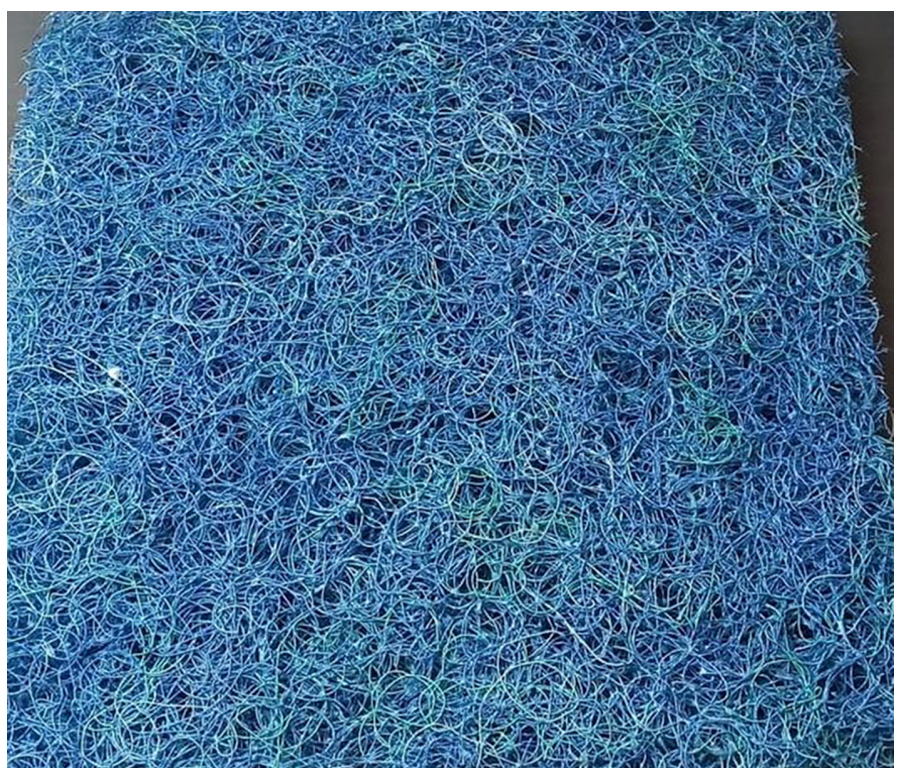

Fig. 4. High porosity nonwoven for filtration and as a biomass carrier in flow-through biofilters (photo by A. Mazur)

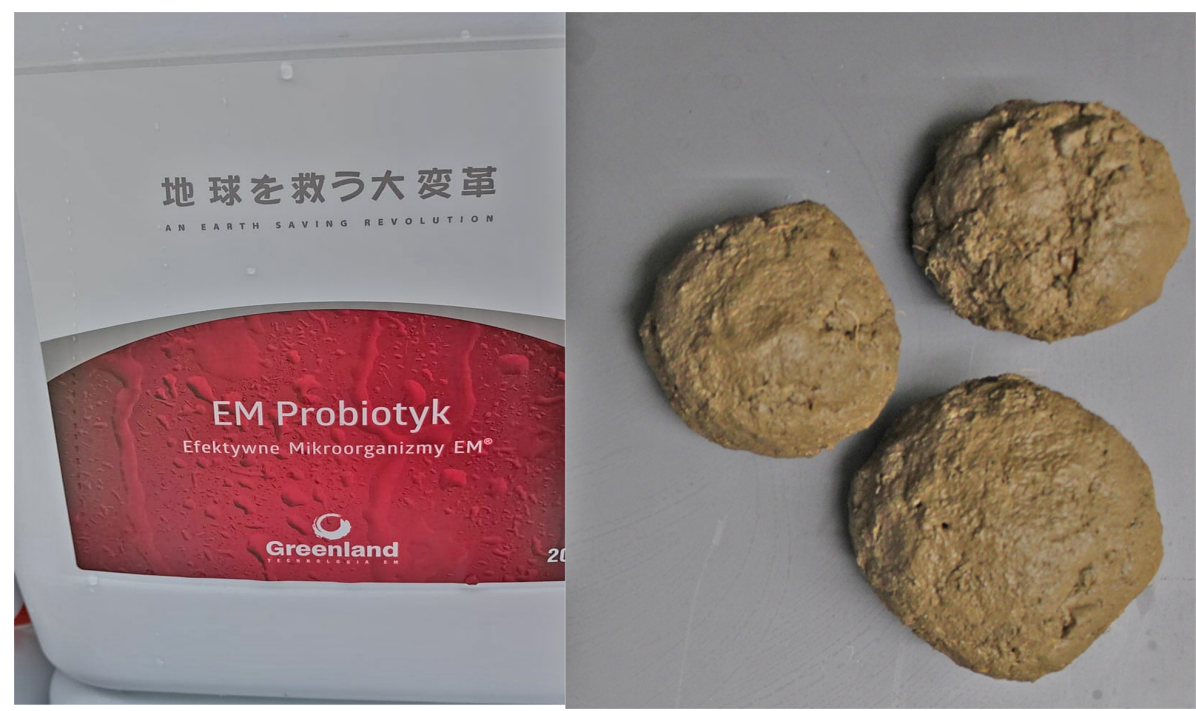

Fig. 5. Bocashi mudball: river clay balls seasoned with the microflora of effective microorganisms and with humus from bio-waste composting (photo by A. Mazur)

and ponds. The only drawback is that it leaves a clay mineral sediment on the bottom after the balls dissolve.

In revitalization of surface water pollution in Poland, biostructures are also used in a form of bags with barley straw previously treated with microbiological biopreparations.
These types of biostructures play a similar role as bokashi mudballs, but additionally influence the conditions for better development of microorganisms from biopreparations applied to contaminated water and stimulate their growth. Practices also translate into quick treatment effects at the place of their application. 


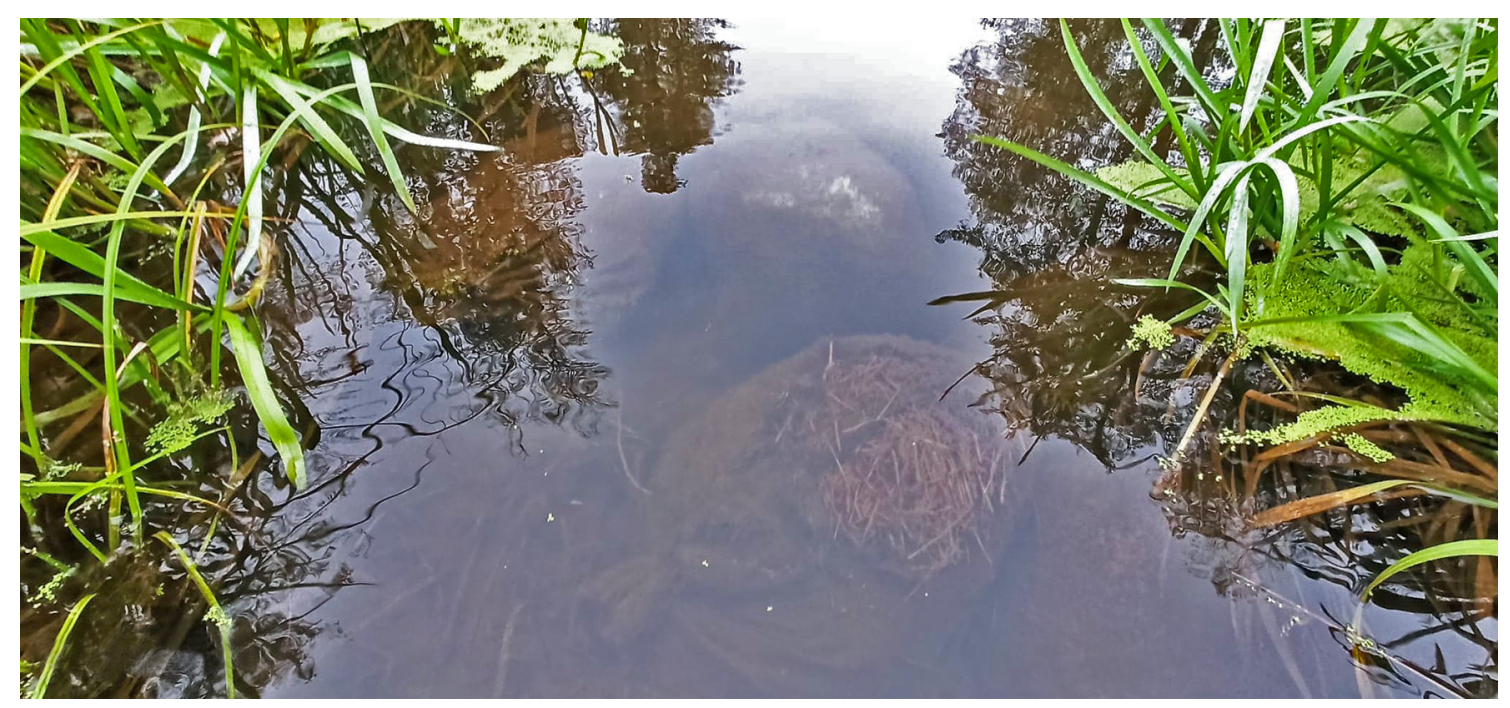

Fig. 6. The biostructures - jute bags with barley straw soaked in microbiological preparations. In practice, bioremediation of water bodies by ACS Poland (photo by A. Mazur)

\section{Microbiological biopreparations}

Microbiological biopreparations are the leader in many branches of industry, i.e. the food industry, health care products, cosmetics, purification processes, agriculture, processes of the revitalization of contaminated soils and waters, elimination of odors and pathogenic microorganisms (hazardous to the health of end consumers of humans, animals, and plants) (Zakaria et al., 2010; Park et al., 2016; Sitarek et al., 2017; Dondajewska et al., 2019; Mazur, 2020; Sharip et al., 2020). The process of their production and the methods used are the result of vigorous research and achievements in the scientific discipline of Biotechnology (its various departments).

Consortia of probiotic microorganisms used in the protection of surface waters are developed by many biotechnology companies and research units. On the market, we can buy powdered or solid biopreparations (tablets) with freeze-dried forms of effective microorganisms spores. They are widely used all over the world for the active protection and treatment of surface waters (small and large water reservoirs) (Mazur, 2020; Sharip et al., 2020). The main advantage of their use is the ease of transport and dosing into water. The disadvantages include the significantly extended time required for the awakening of cryptobiotic forms and their adaptation to a new living environment before the effective process of pollutant biodegradation begins. Revitalization of degraded reservoirs with the use of solid biopreparations is one of the more expensive solutions in the category of biological methods, therefore in Poland, these are niche activities, Eco-Tabs products are mainly used. Liquid biopreparations are also very effective in reducing water pollution and revitalizing degraded water reservoirs (Park; 2016; Mazur, 2020). The success of their operation is not only the composition of the introduced consortia of microorganisms but also complementary substances (stimulating their early development in polluted waters of the reservoir). This form of preparation does not contain spore forms, and when introduced to the reservoir, biodegradation processes begin immediately. Specialized companies are refining the methods of their introduction, stimulation by aeration, etc. On the Polish market, ACS Poland officially reports that over 300 reservoirs have been treated using liquid forms of directional biopreparations (Mazur and Sitarek, 2020). The commercial biopreparations used contain strains of allochthonous microorganisms that are able to effectively reduce various forms of organic pollutants and nutrients in degraded water reservoirs (Swayne et al., 2010). The ACS company also offers a number of liquid preparations dedicated to 
Mazur, A., Chmielowski, K. (2020). Supporting the water reservoir restoration processes by using selected type of biological beds. Acta Sci. Pol., Formatio Circumiectus, 19 (3), 83-98. DOI: http://dx.doi.org/10.15576/ASP.FC/2020.19.3.83

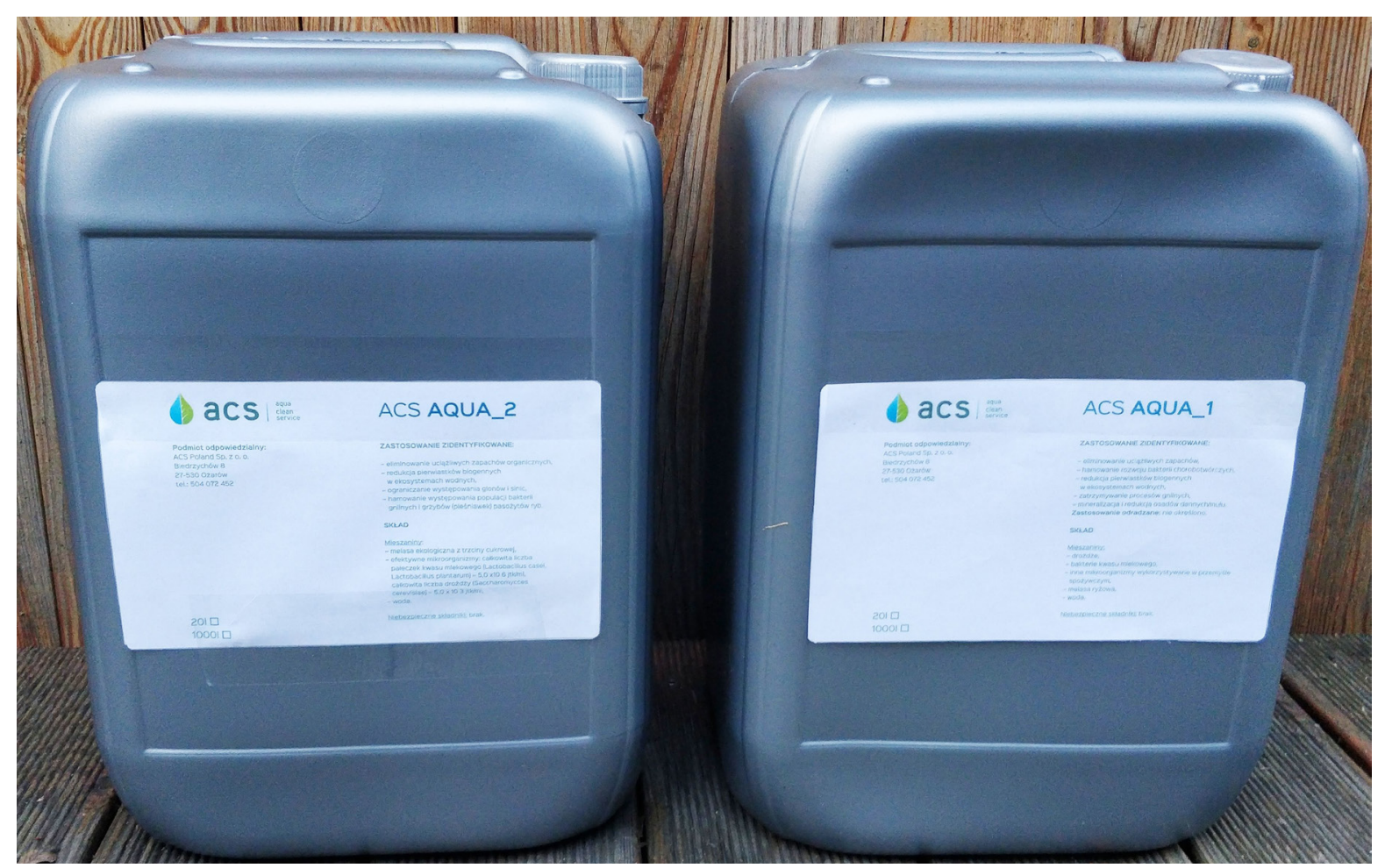

Fig. 7. Microbiological biopreparations of ACS used in the treatment of polluted surface waters (photo by A. Mazur)

the processes of lakes and small water reservoirs revitalization (see: Fig. 7).

Strains of microorganisms from microbiological preparations constitute a diffuse type of biological bed. In the form of allochthonous free-living microorganisms, but with a very high density compared to the indigenous forms.

\section{DISCUSSION}

The process of revitalization of water reservoirs is one of the most complex activities in the field of environmental engineering. Each action taken should be adapted to the nature of the pollution and the geometric parameters of the reservoir (Chmist and Hämmerling, 2016; Nowak et al., 2018; Mazur, 2019b). If the condition of a reservoir is not critical and it is possible to take non-invasive measures, such methods should be selected (Mazur and Sitarek, 2020). The least invasive technologies include biological methods (Mazur, 2020). If the sources of emissions are not fully controlled and they cannot be eliminated, additional technologies supporting treatment processes are recommended (Park; 2016; Sitarek et al., 2017).

Biological beds can significantly support the reservoir treatment process and prevent the negative effects of emissions from diffuse sources (Tanaka et al., 2001; Ateia et al., 2016; Mazur, 2019b). Among the methods described, regardless of the others, applications of microbiological biopreparations is main method (Mazur, 2020). Many scientific publications present the results of revitalization using this type of technology (Zakaria et al., 2010; Park et al., 2016; Sitarek et al., 2017; Dondajewska et al., 2019; Mazur, 2020; Sharip et al., 2020). Additional treatment-enhancing technologies are mainly based on aeration processes (Carr and Martin, 1978; Dixit et al., 2007; Dong et al., 2012; Chmielowski et al., 2019; Anber et al., 2020), or controlled planting of ecotones in zones of intensive nutrient supply to water (Vought et al., 1994; Fennessy and Cronk, 1997; Holland, 2012). 
From the industry practice in the field of aquaculture, we can find information about supporting the treatment process by using bioreactors or appropriately adapted band ditches (as flow biofilters) (Klapper, 2002; Karakurt-Fischer et al., 2020). The use of moving beds requires additional installations with a separate aerated bioreactor chamber operating in the continuous flow or continuous quasi mode (Mazur, 2019B). Active sludge bioreactors are not practiced due to a possible retention of the flocs to the reservoir and a low tolerance of the bed to low pollutant loads (Mazur, 2019b). MBBR bioreactors (Ødegaard et al., 2004) are much more tolerant to changes in environmental parameters. Biomass carriers circulating in the reactor chamber can be easily secured against their retention to breeding ponds or revitalized reservoirs (Mazur, 2019B). The choice of carriers due to their treatment efficiency is indicated by the Kaldnes or Mutag BioChip beds (Andreottola et al., 2000; Ødegaard et al., 2004; Rauch, 2014; Geiger and Rauch, 2017). Due to the price of the beds, a cheaper alternative are recycled beds or flowthrough biofilters with expanded clay or ceramic feed (Łopata et al., 2017). Unfortunately, cheaper beds are characterized by a much smaller active surface of the biofilm and worse treatment parameters per $1 \mathrm{~m} 3$ of the bioreactor (Mazur, 2019b). In such situations, the number of bioreactors used should be higher (Mazur, 2019b). The energy consumption of the treatment process is also significantly higher (Mazur, 2019b). In flow-through reservoirs, nonwovens or porous structures are used to cover the bottom of the reservoir (Szlauer and Świerczyńska, 1988). Under such flow conditions and intensive water oxygenation, the biological membrane growing on the biostructures plays an important role in the water self-purification process (see: Fig. 6).

Unfortunately, none of the biological methods based on fixed or movable beds works independently in the conditions of contaminated stagnant waters and can be used as an auxiliary. In degraded lakes, bays, and places with water stagnation are particularly suitable for the location of bioreactors (Mazur, 2020). Such places are particularly susceptible to secondary effects of eutrophication even during the revitalization process, therefore it is important to use additional supporting techniques (Mazur and Sitarek, 2020).
In ponds and shallow reservoirs up to a depth of about $1 \mathrm{~m}$, very good revitalization results are demonstrated by the methods using bokashi mudballs, as an alternative to direct application of biopreparations to water (Zakaria et al., 2010). Opinions on the control of cyanobacteria by microorganisms from the application of biopreparations are significantly divided. Lurling et al. presented the results of their research showing that effective microorganisms are not able to successfully prevent cyanobacteria blooms in neutralized water bodies (Lurling et al., 2010). The results of the monitoring of Mazur and Mazur and Sitarek showed a significant reduction of cyanobacteria blooms in revitalized water reservoirs (Mazur, 2020; Mazur and Sitarek 2020). Such different test results may result from many reasons, such as application technique and form of biopreparations, field conditions of reservoirs, elimination of pollution sources, etc. Some scientists and experts are concerned about the uncontrolled expansion of new strains of allochthonous microorganisms introduced into the polluted aquatic environment. There are also concerns about the unpredictable effects that this artificial microbiota may have in the new environment (Shalaby, 2011; Nathaniel et al., 2020). The application of biological preparations is recommended only when the degradation state of the water reservoir exceeds the possibilities of water self-purification processes. The polluted waters are dominated by dangerous forms of pathogenic microorganisms, causing a number of adverse environmental changes. Under such conditions, it was shown that the used consortia of microorganisms in biopreparation contribute to the improvement of water quality, reduction of pathogenic microorganisms, and the regeneration of biodiversity appropriate for a given water ecosystem. (Mazur and Sitarek, 2020). Legal regulations concerning the introduction of artificial microbiota into water reservoirs require $\mathrm{PZH}$ approvals, that there are no pathogenic microorganisms in the introduced biomixtures. The potential benefits of the biopreparations used to exceed the risk of the threat posed by foreign strains of microbiota, and the literature reports show positive effects in restoring the level of biodiversity that characterized the reservoir before its contamination. (Mazur, 2020). A very effective combination is the use of bio-mixtures with the planting of macrophytes that create ecotones, such 
methods set new trends in environmental biotechnology in activities for the revitalization of degraded water areas.

The experience of experts performing revitalization processes is also crucial in obtaining the appropriate treatment effect and its durability over time. The biotechnology company ACS Poland has been successful in successful revitalization for over 10 years, revitalized over 300 small and large reservoirs in Poland (Mazur, 2020; Sitarek et al., 2017).

In a few cases, the durability of the revitalization effects is achieved for more than one season, and the treatments have to be repeated. Perhaps the use of bioreactors will help to extend the durability of treatment effects without the need for secondary applications of microbiological preparations (Mazur, 2019b).

\section{CONCLUSIONS}

Biological beds are especially widely used in the treatment of wastewater from various sources. Some of the biological beds can be used in the treatment of open reservoirs, after appropriate adaptation of the treatment installation to the reservoir conditions. The methods based on moving and fixed beds can in most cases be used as support technologies (mainly for biotechnological methods based on the application of microbiological preparations). Further research is required on the possibilities of effective use of carriers in the revitalization of small and large water reservoirs.

\section{REFERENCES}

Al-Amshawee, S. K., Yunus, M. Y., Azoddein, A. A. (2020). A Novel Microbial Biofilm Carrier for Wastewater Remediation. MS\&E, 736(7), 072006.

Álvarez, X., Valero, E., Santos, R. M., Varandas, S. G. P., Fernandes, L. S., Pacheco, F. A. L. (2017). Anthropogenic nutrients and eutrophication in multiple land use watersheds: Best management practices and policies for the protection of water resources. Land Use Policy, 69, 1-11.

Anber, F., Iqra, N. A., Badruzzaman, A. B. M. (2020, April). Restoration of Hatirjheel Lake by designing submerged aeration system and settling zone. In IOP Conference Series: Earth and Environmental Science (476, 1, p. 012138). IOP Publishing.
Andersson, S., Nilsson, M., Dalhammar, G., Kuttuva Rajarao, G. (2008). Assessment of carrier materials for biofilm formation and denitrification. Vatten, 64, 201-207.

Andreadakis, A. D. (1993). Physical and chemical properties of activated sludge floc. Water research, 27(12), 1707-1714.

Andreottola, G., Foladori, P., Ragazzi, M., Tatano, F. (2000). Experimental comparison between MBBR and activated sludge system for the treatment of municipal wastewater. Water Science \& Technology, 41(4), 375-382.

Ateia M, Nasr M., Yoshimura C., Fujii M. (2015) Organic Matter Removal from Saline Agricultural Drainage Wastewater Using a Moving Bed Biofilm Reactor. Water Science \& Technology, 72, 1327-1333

Ateia, M., Yoshimura, C., Nasr, M. (2016). In-situ biological water treatment technologies for environmental remediation: a review. J Bioremed Biodeg, 7(348), 2.

Badejo, A. A., Omole, D. O., Ndambuki, J. M., Kupolati, W. K. (2017). Municipal wastewater treatment using sequential activated sludge reactor and vegetated submerged bed constructed wetland planted with Vetiveria zizanioides. Ecological Engineering, 99, 525-529.

bin Ahmad Nazria, M. A., binti Ghazali, N. L. (2017). The Effectiveness EM Mudball and Banana Peels for Textile Wastewater Treatment. In MATEC Web of Conferences (87, 01009). EDP Sciences.

Borghei, S. M., Sharbatmaleki, M., Pourrezaie, P., Borghei, G. J. B. T. (2008). Kinetics of organic removal in fixed-bed aerobic biological reactor. Bioresource technology, 99(5), 1118-1124.

Brix, H., Schierup, H. H., Arias, C. A. (2007). Twenty year's experience with constructed wetland systems in Denmark-what did we learn?. Water Science and Technology, 56(3), 63-68.

Butt, N., Beyer, H. L., Bennett, J. R., Biggs, D., Maggini, R., Mills, M., Possingham, H. P. (2013). Biodiversity risks from fossil fuel extraction. Science, 342(6157), 425-426.

Cao W, Zhang H, Wang Y, Pan J (2012) Bioremediation of polluted surface water by using biofilms on filamentous bamboo. Ecological engineering 42, 146-149.

Carr, J. E., Martin, D. F. (1978). Aeration efficiency as a means of comparing devices for lake restoration. Journal of Environmental Science \& Health Part A, 13(1), 73-85

Chen, L., Giesy, J. P., Xie, P. (2018). The dose makes the poison. Science of The Total Environment, 621, 649-653. 
Chen, X. F., Chuai, X. M., Zeng, J., Liu, T., Yang, L. Y. (2012). Nitrogenous fluxes and its self-purification capacity in Lake Taihu. Huan jing ke xue= Huanjing kexue, 33(7), 2309-2314.

Chin, D. A. (2012). Water-quality engineering in natural systems: fate and transport processes in the water environment. John Wiley \& Sons.

Chmielowski, K., Mazur, R., Dacewicz, E. (2019). Badania efektywności natleniania ścieków przy zastosowaniu nowych technologii dyfuzorów mikropęcherzykowych. Przemysł Chemiczny, 98.

Chmist, J., Hämmerling, M. (2016). Wybór najskuteczniejszej metody rekultywacji zbiorników wodnych z wykorzystaniem metody AHP. Acta. Sci. Pol., Formatio Circumiectus, 15(2), 27-39.

Cooke, G. D., Welch, E. B., Peterson, S., Nichols, S. A. (2016). Restoration and management of lakes and reservoirs. CRC press.

Cooper, P. (1999). A review of the design and performance of vertical-flow and hybrid reed bed treatment systems. Water Science and Technology, 40(3), 1-9.

Das, B. K. (2005). Environmental pollution impact on water and sediments of Kumaun lakes, Lesser Himalaya, India: a comparative study. Environmental Geology, 49(2), 230-239.

de Jonge, V. N., Elliott, M., Orive, E. (2002). Causes, historical development, effects and future challenges of a common environmental problem: eutrophication. In Nutrients and eutrophication in estuaries and coastal waters (1-19). Dordrecht: Springer.

Dixit, S., Verma, N., Tiwari, S., Mishra, D. D. (2007). An innovative technique for lake management with reference to aeration unit installed at lower lake, Bhopal, India. Environmental monitoring and assessment, 124(1-3), 33-37.

Dondajewska, R., Kozak, A., Rosińska, J., Gołdyn, R. (2019). Water quality and phytoplankton structure changes under the influence of effective microorganisms (EM) and barley straw-Lake restoration case study. Science of the Total Environment, 660, $1355-1366$.

Dong H, Qiang Z, Li T, Jin H, Chen, W. (2012) Effect of artificial aeration on the performance of vertical-flow constructed wetland treating heavily polluted river water. Journal of Environmental Sciences, 24, 596-601 .

Dumont, E., Williams, R., Keller, V., Voß, A., Tattari, S. (2012). Modelling indicators of water security, water pollution and aquatic biodiversity in Europe. Hydrological sciences journal, 57(7), 1378-1403.
Effler, S. W. (1996). Limnological and engineering analysis of a polluted urban lake: prelude to environmental management of Onondaga Lake, New York. Springer Science \& Business Media.

Falconer, I. R. (1996). Potential impact on human health of toxic cyanobacteria. Phycologia, 35(sup6), 6-11.

Fennessy, M. S., Cronk, J. K. (1997). The effectiveness and restoration potential of riparian ecotones for the management of nonpoint source pollution, particularly nitrate. Critical reviews in environmental science and technology, 27(4), 285-317.

Fuhrman, J. (1992). Bacterioplankton roles in cycling of organic matter: the microbial food web. In Primary productivity and biogeochemical cycles in the sea (361-383). Springer, Boston, MA.

Geiger, M., Rauch, B. (2017). Diffusion depth: a crucial factor for MBBR carrier. Filtration+ Separation, 54(1), 30-32.

Goel, P. K. (2006). Water pollution: causes, effects and control. New Age International.

Gołdyn, R., Podsiadłowski, S., Dondajewska, R., Kozak, A. (2014). The sustainable restoration of lakes-towards the challenges of the Water Framework Directive. Ecohydrology \& Hydrobiology, 14(1), 68-74.

Gough, H. L., Stahl, D. A. (2011). Microbial community structures in anoxic freshwater lake sediment along a metal contamination gradient. The ISME journal, 5(3), 543-558.

Ham, J., Yoon, C. G., Kim, H. J., Kim, H. C. (2010). Modeling the effects of constructed wetland on nonpoint source pollution control and reservoir water quality improvement. Journal of Environmental Sciences, 22(6), 834-839.

Han, M. W., Park, Y. C. (1999). The development of anoxia in the artificial Lake Shihwa, Korea, as a consequence of intertidal reclamation. Marine Pollution Bulletin, 38(12), 1194-1199.

Hertkorn, N., Claus, H., Schmitt-Kopplin, P. H., Perdue, E. M., Filip, Z. (2002). Utilization and transformation of aquatic humic substances by autochthonous microorganisms. Environmental science \& technology, 36(20), 4334-4345.

Holland, M. (ed.). (2012). Ecotones: the role of landscape boundaries in the management and restoration of changing environments. Springer Science \& Business Media.

Huang, J., Xu, C. C., Ridoutt, B. G., Wang, X. C., Ren, P. A. (2017). Nitrogen and phosphorus losses and eutrophication potential associated with fertilizer application to cropland in China. Journal of Cleaner Production, 159, 171-179. 
Mazur, A., Chmielowski, K. (2020). Supporting the water reservoir restoration processes by using selected type of biological beds. Acta Sci. Pol., Formatio Circumiectus, 19 (3), 83-98. DOI: http://dx.doi.org/10.15576/ASP.FC/2020.19.3.83

Ilnicki, P., Zeitz, J. (2002). 2 CHAPTER Irreversible Loss of Organic Soil Functions after Reclamation. Organic soils and peat materials for sustainable agriculture, 15.

Johnston, E. L., Roberts, D. A. (2009). Contaminants reduce the richness and evenness of marine communities: a review and meta-analysis. Environmental Pollution, 157(6), 1745-1752.

Joner, E., Leyval, C. (2003). Phytoremediation of organic pollutants using mycorrhizal plants: a new aspect of rhizosphere interactions. Agronomie, 23(5-6), 495-502 .

Juang D, Tsai W, Liu W, Lin J (2008) Treatment of polluted river water by a gravel contact oxidation system constructed under riverbed. International Journal of Environmental Science \& Technology, 5, 305-314.

Karakurt-Fischer, S., Sanz-Prat, A., Greskowiak, J., Ergh, M., Gerdes, H., Massmann, G., Drewes, J. E. (2020). Developing a novel biofiltration treatment system by coupling high-rate infiltration trench technology with a plug-flow porous-media bioreactor. Science of The Total Environment, 722, 137890.

Khan, M. N., \& Mohammad, F. (2014). Eutrophication: challenges and solutions. In Eutrophication: Causes, consequences and control (1-15). Springer: Dordrecht.

Klapper, H. (2002). Mining lakes: generation, loading and water quality control. In Remediation of Abandoned Surface Coal Mining Sites Springer: Berlin, Heidelberg, 57-110.

Kruszelnicka, I., Kramarczyk, D. G., Poszwa, P., Stręk, T. (2018). Influence of MBBR carriers' geometry on its flow characteristics. Chemical Engineering and Processing-Process Intensification, 130, 134-139.

Kuiper, I., Lagendijk, E. L., Bloemberg, G. V., Lugtenberg, B. J. (2004). Rhizoremediation: a beneficial plant-microbe interaction. Molecular plant-microbe interactions, 17(1), 6-15.

Kujawiak, S., Makowska, M., Matz, R. (2018). Hydraulic characteristics of the airlift pump. Acta Scientiarum Polonorum. Formatio Circumiectus, 17(4), 85.

Kujawiak, S., Makowska, M., Mazurkiewicz, J. (2020). The Effect of Hydraulic Conditions in Barbotage Reactors on Aeration Efficiency. Water, 12(3), 724.

Kujawiak, S., Makowska, M., Matz, R., Gawrońska, A. (2017). The efficiency of the aeration process in airlift reactors with moving beds. Technical Transactions, 10(3), 167-172.

Lariyah, M. S., Mohiyaden, H. A., Hayder, G., Hussein, A., Basri, H., Sabri, A. F., Noh, M. N. (2016, March). Application of moving bed biofilm reactor (MBBR) and integrated fixed activated sludge (IFAS) for biological river water purification system: a short review. In IOP Conference Series: Earth and Environmental Science (32, 1, p. 012005). IOP Publishing.

Le, C., Zha, Y., Li, Y., Sun, D., Lu, H., Yin, B. (2010). Eutrophication of lake waters in China: cost, causes, and control. Environmental management, 45(4), 662-668.

Leiknes T. and Ødegaard H. (2007). The development of a biofilm membrane bioreactor. Desalination, 202(1), 135-143.

Lemmer, H., Zaglauer, A., Metzner, G. (1997). Denitrification in a methanol-fed fixed-bed reactor. Part 1. Physico-chemical and biological characterization. Water Research, 31(8), 1897-1902.

Livingston, R. J. (2000). Eutrophication processes in coastal systems: origin and succession of plankton blooms and effects on secondary production in Gulf Coast estuaries. CRC press.

Łopata, M., Czerniejewski, P., Wiśniewski, G., Czerniawski, R., Drozdowski, J. (2017). The use of expanded clay aggregate for the pretreatment of surface waters on the example of a tributary of Lake Klasztorne Górne in Strzelce Krajeńskie. Limnological Review, 17(1), 3-9.

Lu, Y. F., Ma, L. J., Ma, L., Shan, B., Chang, J. J. (2018). Improvement of start-up and nitrogen removal of the anammox process in reactors inoculated with conventional activated sludge using biofilm carrier materials. Environmental technology, 39(1), 59-67.

Lurling, M., Tolman, Y., van Oosterhout, F. (2010). Cyanobacteria blooms cannot be controlled by Effective Microorganisms (EM®) from mud-or Bokashi-balls. Hydrobiologia, 646(1), 133-143.

Maiti, S. K., Chowdhury, A. (2013). Effects of anthropogenic pollution on mangrove biodiversity: a review. Journal of Environmental Protection, 2013.

Mamatarkova, V., Nikolov, L., Karamanev, D. (2002). Biofilms: problems and trends in research activity. Part I: biofilm carriers. Biotechnology \& Biotechnological Equipment, 16(1), 170-176.

Martin, S. (2004). The cost of restoration as a way of defining resilience: a viability approach applied to a model of lake eutrophication. Ecology and Society, 9(2).

Mazur, R. (2019) A. Lakes Restoration: Analysis of Terminology Incorrectly Used in the Scientific Literature. Acta Scientiarum Polonorum. Formatio Circumiectus, 18(2), 135-146. DOI: https://doi.org/10.15576/ ASP.FC/2019.18.2.135 
Mazur, A., Chmielowski, K. (2020). Supporting the water reservoir restoration processes by using selected type of biological beds. Acta Sci. Pol., Formatio Circumiectus, 19 (3), 83-98. DOI: http://dx.doi.org/10.15576/ASP.FC/2020.19.3.83

Mazur, R. (2019)B. The Concept of Polluted Small Water Reservoirs Re-Degradation Technology with the Application of MBBR Reactors. Acta Scientiarum Polonorum. Formatio Circumiectus, 18(2), 121-133. DOI: https://doi.org/10.15576/ASP.FC/2019.18.2.121

Mazur, R. (2020). The Application of Microbiological Biopreparations in The Process of Water Remediation of the Dam Reservoir in Głuchów. Acta Scientiarum Polonorum. Formatio Circumiectus, 19(1), 81-95.

Mazur, R., Siatarek, M. (2020). Microbiological bioremediation of the Kamienna Gora dam reservoir. Acta Scientiarum Polonorum. Formatio Circumiectus, 19(1).

Mazurkiewicz, J., Mazur, A., Mazur, R., Chmielowski, K., Czekała, W., Janczak, D. (2020). The Process of Microbiological Remediation of the Polluted Słoneczko Reservoir in Poland: For Reduction of Water Pollution and Nutrients Management. Water, 12(11), 3002.

McGuire, J. T., Cozzarelli, I. M., Bekins, B. A., Link, H., Martinović-Weigelt, D. (2018). Toxicity assessment of groundwater contaminated by petroleum hydrocarbons at a well-characterized, aged, crude oil release site. Environmental science \& technology, 52(21), 12172-12178.

McQuarrie, J. P., Boltz, J. P. (2011). Moving bed biofilm reactor technology: process applications, design, and performance. Water Environment Research,83(6), $560-575$

Moga, I. C., Iordache, O. I., Petrescu, G., Pricop, F., Dumitrescu, I. (2018, June). Polyethylene based materials for biofilm carriers used in wastewater treatment. In International Conference on Innovative Research, Iasi, 17th-18th of May.

Morgan-Sagastume, F. (2018). Biofilm development, activity and the modification of carrier material surface properties in moving-bed biofilm reactors (MBBRs) for wastewater treatment. Critical reviews in environmental science and technology, 48(5), 439-470.

Mulligan, C. N., Davarpanah, N., Fukue, M., Inoue, T. (2009). Filtration of contaminated suspended solids for the treatment of surface water. Chemosphere, 74(6), 779-786.

Nagaoka, H., Ueda, S., Miya, A. (1996). Influence of bacterial extracellular polymers on the membrane separation activated sludge process. Water Science and Technology, 34(9), 165-172.

Nakamura, K., Mueller, G. (2008). Review of the performance of the artificial floating island as a restoration tool for

Nathaniel, O., Sam, A. R. M., Lim, N. H. A. S., Adebisi, O., Abdulkareem, M. (2020). Biogenic approach for concrete durability and sustainability using effective microorganisms: A review. Construction and Building Materials, 261, 119664.

Nowak, A., Mazur, R., Panek, E., Chmist, J. (2018). Model Studies on the Effectiveness of MBBR Reactors for the Restoration of Small Water Reservoirs. In E3S Web of Conferences (30, 02004). EDP Sciences. Nowak, A., Mazur, R., Panek, E., Dacewicz, E., Chmielowski, K. (2019). Treatment efficiency of fish processing wastewater in different types of biological reactors. Physics and Chemistry of the Earth, Parts $\mathrm{A} / \mathrm{B} / \mathrm{C}, 109,40-48$.

Ødegaard, H., Rusten, B., Wessman, F. (2004). State of the art in Europe of the moving bed biofilm reactor (MBBR) process. In Proceedings of the 77th Annual Water Environment Federation Technical Exposition and Conference, New Orleans, Louisiana, Oct (2-6).

Ontiveros-Cuadras, J. F., Ruiz-Fernández, A. C., Sanchez-Cabeza, J. A., Sericano, J., Pérez-Bernal, L. H., Páez-Osuna, F., Mucciarone, D. A. (2019). Recent history of persistent organic pollutants (PAHs, PCBs, PBDEs) in sediments from a large tropical lake. Journal of hazardous materials, 368, 264-273.

Ostroumov, S. A. (2017). Water quality and conditioning in natural ecosystems: biomachinery theory of self-purification of water. Russian Journal of general chemistry, 87(13), 3199-3204.

Palanques, A., Grimalt, J., Belzunces, M., Estrada, F., Puig, P., Guillén, J. (2014). Massive accumulation of highly polluted sedimentary deposits by river damming. Science of the total environment, 497, 369-381.

Park, G. S., Khan, A. R., Kwak, Y., Hong, S. J., Jung, B., Ullah, I., Shin, J. H. (2016). An improved effective microorganism (EM) soil ball-making method for water quality restoration. Environmental Science and Pollution Research, 23(2), 1100-1107.

Peirce, J. J., Vesilind, P. A., Weiner, R. (1998). Environmental pollution and control. Butterworth-Heinemann.

Qin, H., Ji, B., Zhang, S., Kong, Z. (2018). Study on the bacterial and archaeal community structure and diversity of activated sludge from three wastewater treatment plants. Marine pollution bulletin, 135, 801-807.

Qiu, H. (2011). Migration mechanism of organic pollutants in national water-body sediments. Journal of Geography and Geology, 3(1), 239.

Qu, J., Fan, M. (2010). The current state of water quality and technology development for water pollution control in China. Critical reviews in environmental science and technology, 40(6), 519-560. 
Mazur, A., Chmielowski, K. (2020). Supporting the water reservoir restoration processes by using selected type of biological beds. Acta Sci. Pol., Formatio Circumiectus, 19 (3), 83-98. DOI: http://dx.doi.org/10.15576/ASP.FC/2020.19.3.83

Quan, T. H., Gogina, E., Van Quang, T. (2018). The biological treatment of laboratory SBR model with biofilm. In MATEC Web of Conferences (251, 03029). EDP Sciences.

Rauch, B. J. (2014). Choosing a suitable biofilm carrier media. Filtration+ Separation, 51(5), 32-34.

Shalaby, E. A. (2011). Prospects of effective microorganisms technology in wastes treatment in Egypt. Asian Pacific journal of tropical biomedicine, 1(3), 243-248.

Shao, Y., Chung, B. S., Lee, S. S., Park, W., Lee, S. S., Jeon, C. O. (2009). Zoogloea caeni sp. nov., a floc-forming bacterium isolated from activated sludge. International journal of systematic and evolutionary microbiology, 59(3), 526-530.

Sharip, Z., Razak, S. B. A., Noordin, N., Yusoff, F. M. (2020). Application of an Effective Microorganism Product as a Cyanobacterial Control and Water Quality Improvement Measure in Putrajaya Lake, Malaysia. Earth Systems and Environment, 4(1), 213-223.

Sitarek, M., Napiórkowska-Krzebietke, A., Mazur, R., Czarnecki, B., Pyka, J. P., Stawecki, K., Kapusta, A. (2017). Application of Effective Microorganisms Technology as a lake restoration tool-a case study of Muchawka Reservoir. Elem, 22(2), 529-543.

Smil, V. (2015). The bad earth: Environmental degradation in China. Routledge.

Sonwani, R. K., Swain, G., Giri, B. S., Singh, R. S., Rai, B. N. (2019). A novel comparative study of modified carriers in moving bed biofilm reactor for the treatment of wastewater: Process optimization and kinetic study. Bioresource technology, 281, 335-342.

Sorrell, B. K., Dromgoole, F. I. (1987). Oxygen transport in the submerged freshwater macrophyte Egeria densa Planch. I. Oxygen production, storage and release. Aquatic Botany, 28(1), 63-80.

Stewart, I., Seawright, A. A., Shaw, G. R. (2008). Cyanobacterial poisoning in livestock, wild mammals and birds-an overview. In Cyanobacterial harmful algal blooms: state of the science and research needs (613-637). Springer, New York, NY.

Sutton, M. A., Mason, K. E., Sheppard, L. J., Sverdrup, H., Haeuber, R., Hicks, W. K. (Eds.). (2014). Nitrogen deposition, critical loads and biodiversity. Springer Science \& Business Media.

Swayne, D. A., Yang, W., Voinov, A. A., Rizzoli, A., Filatova, T. (2010). Effective Microorganisms (EM) Technology for Water Quality Restoration and Potential for Sustainable Water Resources and Management.

Szlauer, L., Świerczyńska, I. (1988). The role of artificial substrate in polluted stream. Zeszyty Naukowe Akademii Rolniczej w Szczecinie, 133, 39-47.
Tanaka, T., Tsuzuki, K., Nishijima, N., Takagi, T. 2001. Algae-removal performance of a fluidized-bed biofilm reactor system for lake water treatment. Water science and technology, 43(1), 277-283.

Tripathi, A. K., Pandey, S. N. (2009). Water pollution. APH Publishing.

Tzeng, C. J., Iranpour, R., Stenstrom, M. K. (2003). Modeling and control of oxygen transfer in high purity oxygen activated sludge process. Journal of Environmental Engineering, 129(5), 402-411.

Vanrolleghem, P. A. (2002, October). Principles of respirometry in activated sludge wastewater treatment. In Proceedings International Workshop on Recent Development in Respirometry for Wastewater Treatment Plant Monitoring and Control, Taipei, Taiwan (p. 2).

Vought, L. B. M., Dahl, J., Pedersen, C. L., Lacoursiere, J. O. (1994). Nutrient retention in riparian ecotones. Ambio, 342-348.

Walters, E., Hille, A., He, M., Ochmann, C., Horn, H. (2009). Simultaneous nitrification/denitrification in a biofilm airlift suspension (BAS) reactor with biodegradable carrier material. Water research, 43(18), 4461-4468.

Wang, D., Wang, Y., Singh, V. P., Zhu, J., Jiang, L., Zeng, D., Zeng, C. (2018). Ecological and health risk assessment of PAHs, OCPs, and PCBs in Taihu Lake basin. Ecological Indicators, 92, 171-180.

Wang, G., Wang, D., Xu, Y., Li, Z., Huang, L. (2020). Study on optimization and performance of biological enhanced activated sludge process for pharmaceutical wastewater treatment. Science of The Total Environment, 739, 140166.

Wang, W., Tang, X. Q., Huang, S. L., Zhang, S. H., Lin, C., Liu, D. W., Scholz, M. (2010). Ecological restoration of polluted plain rivers within the Haihe River Basin in China. Water, Air, \& Soil Pollution, 211(1-4), 341-357.

Wei, G., Yang, Z., Cui, B., Li, B., Chen, H., Bai, J., Dong, S. (2009). Impact of dam construction on water quality and water self-purification capacity of the Lancang River, China. Water resources management, 23(9), 1763-1780.

Wilderer, P. A., Arnz, P., Arnold, E. (2000). Application of biofilms and biofilm support materials as a temporary sink and source. In Environmental Challenges (147158). Springer: Dordrecht.

Zainab, A., Meraj, S., Liaquat, R. (2020). Study on natural organic materials as biofilm carriers for the optimization of anaerobic digestion. Waste and Biomass Valorization, 11(6), 2521-2531.

Zakaria, Z., Gairola, S., Shariff, N. M. (2010). Effective microorganisms (EM) technology for water quality resto- 
ration and potential for sustainable water resources and management.

Zaldívar, J. M., Viaroli, P., Newton, A., De Wit, R., Ibañez, C., Reizopoulou, S., Murray, N. (2008). Eutrophication in transitional waters: an overview. Transitional Waters Monographs, 2(1), 1-78.
Zedler, J. B. (2000). Progress in wetland restoration ecology. Trends in ecology \& evolution, 15(10), 402-407.

Zhang, B., Xu, X., Zhu, L. (2017). Structure and function of the microbial consortia of activated sludge in typical municipal wastewater treatment plants in winter. Scientific reports, $7(1), 1-11$.

\section{WSPOMAGANIE PROCESU REWITALIZACI ZBIORNIKÓW WODNYCH PRZEZ ZASTOSOWANIE WYBRANYCH TYPÓW ZŁÓŻ BIOLOGICZNYCH}

\section{ABSTRAKT}

\section{Cel pracy}

Celem pracy jest ocena możliwości wykorzystania wybranych typów złóż biologicznych we wspomaganiu procesów rewitalizacji silnie zdegradowanych zbiorników wodnych.

\section{Materiat i Metody}

Autorzy dokonali przeglądu literatury w zakresie złóż biologicznych stosowanych w procesach oczyszczania różnych typów ścieków. Wybrano określone typy złoży, które wykazują tolerancję na zmiany temperatury oraz znaczące zmiany ładunków zanieczyszczeń organicznych. Scharakteryzowano potencjał samooczyszczania wód oraz rolę naturalnych metod w rewitalizacji zbiorników wodnych. Przedstawiono charakterystykę metod biologicznych opartych na złożach ruchomych MBBR oraz złożach stałych.

\section{Wyniki i wnioski}

Ocenie poddano możliwości zastosowania wybranych typów złóż ruchomych MBBR i stałych we wspomaganiu procesu oczyszczania silnie zanieczyszczonych wód powierzchniowych. Dyskusji poddano metody biotechnologiczne oparte na biopreparatach płynnych i stałych stosowanych standardowo w rewitalizacji wód. Wykazano, że w przypadku gdy metody biotechnologiczne nie są w stanie sprawnie działać, bardzo korzystne jest uruchomienie dodatkowych procesów biologicznych w celu poprawy efektywności procesu rewitalizacji.

Słowa kluczowe: złoża biologiczne, nośniki biomasy, MBBR, filtry włókninowe, złoża mineralne, zanieczyszczenie wód, oczyszczanie wód 